\title{
Correction to: Self-Reported Sleep and Exercise Patterns in Patients with Schizophrenia: A Cross-Sectional Comparative Study
}

\author{
Nancy Kiwan ${ }^{1} \cdot$ Ziyad Mahfoud $^{2,3} \cdot$ Suhaila Ghuloum ${ }^{4} \cdot$ Rifka Chamali $^{1} \cdot$ Arij Yehya $^{1} \cdot$ Samer Hammoudeh $^{1}$. \\ Yahya Hani ${ }^{4} \cdot$ Iman Amro ${ }^{1} \cdot$ Hassen Al-Amin ${ }^{5}$
}

Published online: 22 January 2020

(C) The Author(s) 2020

\section{Correction to: International Journal of Behavioral Medicine}

https://doi.org/10.1007/s12529-019-09830-2

The original article has been corrected:

The article Self-Reported Sleep and Exercise Patterns in Patients with Schizophrenia: a Cross-Sectional Comparative Study written by Nancy Kiwan, Ziyad Mahfoud, Suhaila Ghuloum, Rifka Chamali, Arij Yehya, Samer Hammoudeh, Yahya Hani, Iman Amro, and Hassen Al-Amin was originally published electronically on the publisher's internet portal (currently SpringerLink) on 17 December 2019 incorrectly without Open Access.

This is now corrected, and the copyright of the article changed on January 2020 to $($ ) The Author(s) 2020 and the article is forthwith distributed under the terms of the Creative Commons Attribution 4.0 International License (https://creativecommons. org/licenses/by/4.0/), which permits use, duplication, adaptation, distribution, and reproduction in any medium or format, as long as appropriate credit is given to the original author(s) and the source, a link to the Creative Commons license is provided, and any changes that were made are specified.

The online version of the original article can be found at https://doi.org/ 10.1007/s12529-019-09830-2

Hassen Al-Amin

haa2019@qatar-med.cornell.edu

1 Department of Research, Weill Cornell Medicine-Qatar, Doha, Qatar

2 Department of Health Policy and Research, Weill Cornell Medicine-Qatar, Doha, Qatar

3 Department of Healthcare Policy and Research, Weill Cornell Medicine, New York, NY, USA

4 Psychiatry Hospital, Hamad Medical Corporation, Doha, Qatar

5 Department of Psychiatry, Weill Cornell Medicine-Qatar, Education City, P.O. Box 24144, Doha, Qatar

Open Access This article is licensed under a Creative Commons Attribution 4.0 International License, which permits use, sharing, adaptation, distribution and reproduction in any medium or format, as long as you give appropriate credit to the original author(s) and the source, provide a link to the Creative Commons licence, and indicate if changes were made. The images or other third party material in this article are included in the article's Creative Commons licence, unless indicated otherwise in a credit line to the material. If material is not included in the article's Creative Commons licence and your intended use is not permitted by statutory regulation or exceeds the permitted use, you will need to obtain 